\title{
PERENCANAAN JUMLAH PRODUKSI OPTIMAL UNTUK MEMBERIKAN PENDAPATAN MAKSIMAL DI PT. CCAI CENTRAL SUMATERA
}

\author{
Meldia Fitri ${ }^{1}$, Ali Sutan Nasution ${ }^{2}$ \\ ${ }^{1}$ Program Studi Teknik Industri Sekolah Tinggi Teknik Industri (STTIND) Padang \\ ${ }^{2}$ Program Studi Teknik Pertambangan Sekolah Tinggi Teknik Industri (STTIND) Padang \\ Email: meldia.ananda@yahoo.com, alisutannasution@yahoo.co.id
}

\begin{abstract}
PT. Coca Cola Amatil Indonesia (CCAI) is a company engaged in the manufacture of soft drinks agro-industry. In the process of production of PT. CCAI has decreased the amount of production in 2013. To overcome this problem, researchers interested in more depth about the function of the simplex method for optimal production quantities and the maximum income that can be obtained by PT. CCAI. Simplex method is a method of solving problems through recalculation linear program (iteration) which measures the same calculation is repeated many times before the optimum solution is achieved. Simplex method is used to solve the case with many decision variables. In this study, the calculation of the simplex method using software lingo10, variable objective function simplex method in this study is the selling price of the product, raw material concentrates, sugar raw materials, raw materials and raw materials CO2 syrup. From the calculations have been done obtained optimal production quantities which produces Coca Cola 295ml many as 440547.8 crates / year, as many as 44604.35 crates Sprite $295 \mathrm{ml} / 220 \mathrm{ml}$ Frestea year and as many as 464847.8 crates / year so that the maximum income to be obtained by the company amounted to USD 2.235097 billion.
\end{abstract}

Keywords: production, simplex method, revenue, software lingol0

\section{PENDAHULUAN}

PT. Coca Cola Amatil Indonesia (PT CCAI) adalah salah satu perusahaan yang bergerak dalam bidang minuman kemasan botol berbagai merek. Produk minuman yang dihasilkan perusahaan ini antara lain Cocacola, Sprite, Fanta dan Frestea. PT Coca Cola Amatil Indonesia memiliki beberapa anak perusahaan yang salah satunya adalah yang berlokasi di Provinsi Sumatera Barat tepatnya di Kota Padang. Unit produksi PT Coca Cola Amatil Indonesia Central Sumatera ini akan menyuplai beberapa gudang yang berlokasi di kota lain seperti Kota Bukittinggi.

Permasalahan yang dialami oleh PT. Coca Cola Amatil Indonesia Central Sumatera saat ini adalah menurunnya jumlah produksi yang menyebabkan permintaan konsumen tidak terpenuhi. terjadinya penurunan jumlah produksi sehingga berdampak langsung terhadap perolehan pendapatan pada perusahaan Untuk mengatasi masalah ini maka diperlukan sebuah metode. Salah satu metode yang dapat digunakan adalah metode yang berbasis program linear (linear programming).

Program linear (linear programming) merupakan serangkaian persamaan matematis, yang terdiri dari satu variabel terikat dan beberapa variabel bebas yang mempengaruhinya. Salah satu metode yang tepat digunakan pada kasus yang dialami PT Coca Cola Amatil Indonesia Central Sumatera adalah metode simpleks. Metode Simpleks bekerja dengan cara memaksimalkan keterbatasan sumber daya baik itu bahan baku, mesin dan tenaga kerja untuk memaksimalkan pendapatan yang ingin dicapai oleh perusahaan.

Memperhatikan uraian di atas, maka dapat dirumuskan masalah yang melatar belakangi penelitian ini yaitu Berapa jumlah produksi yang optimal dan pendapatan maksimal yang akan diperoleh PT. Coca Cola Amatil Indonesia pada tahun 2014? 
Sesuai dengan latar belakang diatas, tujuan penelitian ini adalah Merencanakan jumlah produksi yang optimal dan pendapatan maksimal yang akan diperoleh perusahaan dengan menggunakan metode simpleks.

\section{METODOLOGI PENELITIAN}

Metoda penelitian yang dilakukan adalah menggunakan metoda simpleks dengan mengaplikasikan software lingo 10. Untuk pengolahan data yang dilakukan dalam penelitiaan ini dengan metode simpleks didasarkan pada gagasan ini, dengan langkahlangkah sebagai berikut: (Sri Mulyono,2007)

1. Dimulai pada suatu titik yang layak, biasanya titik asal (yang disebut sebagai solusi awal)

2. Bergerak dari satu titik pojok layak ke titik pojok yang lain yang berdekatan. Pergerakan ini akan menghasilkan fungsi tujuan yang lebih baik. Jika solusi yang lebih baik telah diperoleh, prosedur simpleks dengan sendirinya akan menghilangkan semua solusi - solusi lain yang kurang baik.

3. Proses ini diulang-ulang sampai suatu solusi ditemukan. Proses simpleks kemudian berhenti dan solusi optimum diperoleh.

Tabel simpleks mengikuti langkahlangkah sebagai berikut :

1. Mengubah fungsi tujuan dan batasan

Fungsi tujuan diubah menjadi fungsi implisit, artinya semua $\mathrm{CjXij}$ digeser kekiri. Model program linear diubah kedalam bentuk standar.

2. Menyusun persamaan-persamaan ke dalam tabel simpleks

Setelah formulasi diubah kemudian disusun dalam tabel, dalam bentuk simbol seperti terlihat dari ketidaksamaan $(\leq)$ menjadi persamaan sama dengan $(=)$ ada tabel berikut ini. Tabel ini digunakan sebagai alat bantu untuk mencari solusi optimal.

3. Memilih kolom kunci (entering variabel / EV)

Adalah kolom atau variabel yang akan memasuki basis. Pilih kolom yang mempunyai nilai pada basis fungsi yang bernilai negatif (persoalan maksimasi) atau sebaliknya dengan angka terbesar.

4. Memilih baris kunci (leaving vaiabel / $L V$ ) Adalah basis yang akan meninggalkan basis dimana memiliki rasio terkecil dengan rumus nilai kolom RHS dibagi dengan kolom kunci.

5. Memilih angka kunci (Leaving Variabel/ $L V)$

Adalah angka pertemuan antara baris kunci dengan kolom kunci. Angka ini merupakan pembagi untuk mencari nilai iterasi terbaru.

Adapun tujuan dari PT. Coca Cola Amatil Indonesia Central Sumatera adalah memaksimalkan pendapatan. Tujuan ini dapat dituliskan dalam bentuk persamaan sebagai berikut :

$\mathrm{FT}=\mathrm{aX}+\mathrm{bX}_{2}+\mathrm{cX} \mathrm{X}_{3}+\mathrm{dX}_{4}+\mathrm{eX}_{5}+\mathrm{fX}_{6}+\mathrm{gX}_{7}$ Dimana Fungsi Tujuan (FT) menunjukkan besarnya pendapatan total $\mathrm{X}_{1}, \mathrm{X}_{2}, \mathrm{X}_{3}, \mathrm{X}_{4}, \mathrm{X}_{5}$, $\mathrm{X}_{6}$ dan $\mathrm{X}_{7}$ masing-masing adalah jumlah maksimum yang di hasilkan.

Batasan/Kendala yaitu :

1. Kandungan konsentrat

2. Kandungan gula

3. Kandungan sirup

4. Kandungan $\mathrm{CO}_{2}$

5. Kapasitas Mesin

Dengan menggunakan software lingo 10 memungkinkan perhitungan masalah pemrograman linear dengan variabel. Untuk menentukan nilai optimal dengan menggunakan Lingo diperlukan beberapa syarat yaitu:

1. Memerlukan fungsi Objektif

Untuk syarat pertama fungsi objektif, bisa dikatakan tujuan. Tujuan disini yaitu maksimasi $(M A X)$. Kata pertama untuk mengawali pengetikan formula pada Lingo adalah $M A X$. Formula yang diketikan ke dalam untitled (papan editor pada Lingo) setelah MAX disebut fungsi tujuan. Secara umum dapat dituliskan sebagai berikut:

Fungsi tujuan model matematika

Maks Z $=\mathrm{C} 1 \mathrm{X}_{1}+\mathrm{C} 2 \mathrm{X}_{2}+\mathrm{C} 3 \mathrm{X}_{3}+\mathrm{C} 4 \mathrm{X}_{4}+$ $\mathrm{C} 5 \mathrm{X}_{5}+\mathrm{C} 6 \mathrm{X}_{6}+\mathrm{C} \mathrm{X}_{7}$

Diketikkan ke dalam untitled menjadi MAX C1 $1 \mathrm{X}_{1}+\mathrm{C} 2 \mathrm{X}_{2}+\mathrm{C} 1 \mathrm{X}_{1}+\mathrm{C} 2 \mathrm{X}_{2}+$ $\mathrm{C} 3 \mathrm{X}_{3}+\mathrm{C} 4 \mathrm{X}_{4}+\mathrm{C} 5 \mathrm{X}_{5}+\mathrm{C} 6 \mathrm{X}_{6}+\mathrm{C} 7 \mathrm{X}_{7}$

2. Batasan atau Kendala

Untuk syarat kedua setelah fungsi objektif selanjutnya adalah batasan atau kendala. Setelah fungsi objektif diketikkan selanjutnya diketikkan Subject to atau $S T$ untuk mengawali pengetikan batasan dan pada baris berikutnya baru diketikkan batasan yang ada diakhir batasan kita akhiri dengan kata END. 
Secara umum dapat dituliskan sebagai berikut:

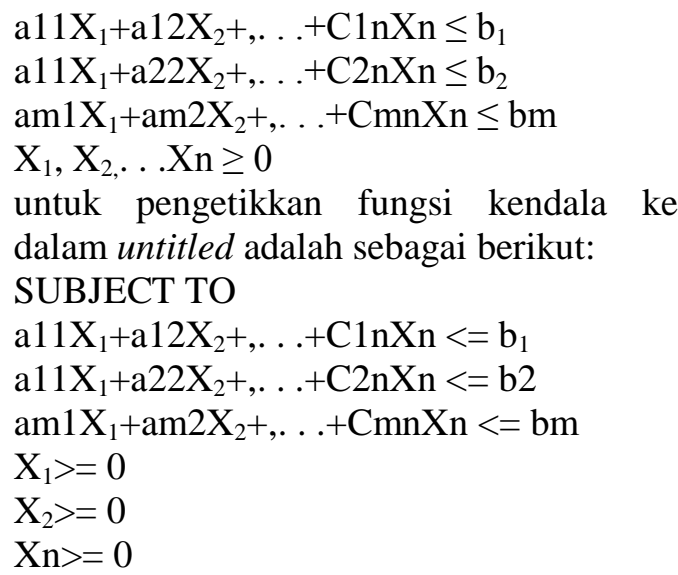

END

\section{HASIL PENELITIAN}

Pengumpulan data merupakan tahap yang dilakukan sebelum pengolahan data dalam menentukan jumlah produksi. Adapun datadata yang akan dikumpulkan adalah data yang berkaitan dengan permasalahan yang disesuaikan Data yang dikumpulkan yaitu :

1. Data jumlah produksi tahun 2013

2. Data jenis produk,

3. Data pemakaian bahan baku

4. Data harga jual produk perbotol

Data yang dikumpulkan diolah dengan menggunakan software Lingo10 seperti persamaan simpleks dibawah ini:

MODEL:

MAX $=1958 * \mathrm{X}_{1}+1958 * \mathrm{X}_{2}+1958 * \mathrm{X}_{3}+$ $2890 * \mathrm{X}_{4}+2890 * \mathrm{X}_{5}+2890 * \mathrm{X}_{6}+1792 * \mathrm{X}_{7}$;

$0.0002 * \mathrm{X}_{1}+0.0001 * \mathrm{X}_{2}+0.0001 * \mathrm{X}_{3}+$ $0.0003 * \mathrm{X}_{4}+0.0002 * \mathrm{X}_{5}+0.0002 * \mathrm{X}_{6}+$ $0.0001 * \mathrm{X}_{7}=187.5$;

$0.02 * X_{1}+0.025 * X_{2}+0.027 * X_{3}+0.03 * X_{4}+$ $0.038 * \mathrm{X}_{5}+0.04 * \mathrm{X}_{6}+0.02 * \mathrm{X}_{7}<=40201.55$;

$0.03 * X_{1}+0.038 * X_{2}+0.04 * X_{3}+0.04 * X_{4}+$ $0.05 * \mathrm{X}_{5}+0.06 * \mathrm{X}_{6}+0.21 * \mathrm{X}_{7}<=218432.81$;

$0.0025 * \mathrm{X}_{1}+0.002 * \mathrm{X}_{2}+0.0016 * \mathrm{X}_{3}+$

$0.0037 * \mathrm{X}_{4}+0.0033 * \mathrm{X}_{5}+0.003 * \mathrm{X}_{6}<=$ 1763.84;

$X_{1}+X_{2}+X_{3}+X_{4}+X_{5}+X_{6}+X_{7}<=950000$

$\mathrm{X}_{1}>0$

$\mathrm{X}_{2}>0$

$\mathrm{X}_{3}>0$

$\mathrm{X}_{4}>0$

$\mathrm{X}_{5}>0$

$\mathrm{X}_{6}>0$

$\mathrm{X}_{7}>0$;

END
Dari model persamaan simpleks dengan software Lingo10 diatas dapat dilihat bahwa :

1. Max merupakan harga jual produk perbotol dari Coca Cola 193ml, Fanta $200 \mathrm{ml}$, Sprite $200 \mathrm{ml}$, Coca Cola $295 \mathrm{ml}$, Fanta $295 \mathrm{ml}$, Sprite $295 \mathrm{ml}$ dan Frestea 220ml. harga jual produk merupakan fungsi tujuan dari perhitungan metoda simpleks.

2. Pada baris pertama merupakan komposisi bahan baku berupa konsentrat masingmasing produk, konsetrat ini merupakan fungsi kendala pertama pada perhitungan metoda simpleks.

3. Pada baris kedua merupakan komposisi bahan baku berupa gula masing-masing produk, gula ini merupakan fungsi kendala kedua pada perhitungan metoda metoda simpleks.

4. Pada baris ketiga merupakan komposisi bahan baku berupa sirup masing-masing produk, sirup ini merupakan fungsi kendala ketiga pada perhitungan metoda simpleks.

5. Pada baris ke empat merupakan komposisi bahan baku berupa $\mathrm{CO}_{2}$ (karbondioksida). $\mathrm{CO}_{2}$ ini akan bereaksi dengan air yang akan menghasilkan minuman berkabonat. $\mathrm{CO}_{2}$ ini merupakan fungsi kendala ke empat pada perhitungan metoda simpleks.

6. Pada baris kelima merupakan kapasitas mesin produksi. Kapasitas mesin produksi merupakan fungsi kendala ke lima pada perhitungan metoda simpleks.

Berdasarkan persamaan simpleks dengan software lingo10 diatas maka didapakan hasil jumlah produksi yang optimal dan pendapatan maksimal pada PT. Coca Cola Amatil Indonesia Central Sumatera untuk tahun mendatang adalah :

Global optimal solution found.

Objective value:

$0.2235097 \mathrm{E}+10$

Total solver iterations: 4

$\begin{array}{ccc}\text { Variable } & \text { Value } & \text { Reduced Cost } \\ \text { X1 } & 0.000000 & 693.3043 \\ \text { X2 } & 0.000000 & 788.7826 \\ \text { X3 } & 0.000000 & 597.8261 \\ \text { X4 } & 440547.8 & 0.000000 \\ \text { X5 } & 0.000000 & 143.2174 \\ \text { X6 } & 44604.35 & 0.000000 \\ \text { X7 } & 464847.8 & 0.000000\end{array}$




$\begin{array}{clr}\text { Row } & \text { Slack or Surplus } & \text { Dual Price } \\ 1 & 0.2235097 \mathrm{E}+10 & 1.000000 \\ 2 & 0.000000 & -3341739 \\ 3 & 15903.98 & 0.000000 \\ 4 & 100516.6 & 0.000000 \\ 5 & 0.000000 & 477391.3 \\ 6 & 0.000000 & 2126.174 \\ 7 & 0.000000 & 0.000000 \\ 8 & 0.000000 & 0.000000 \\ 9 & 0.000000 & 0.000000 \\ 10 & 440547.8 & 0.000000 \\ 11 & 0.000000 & 0.000000 \\ 12 & 44604.35 & 0.000000 \\ 13 & 464847.8 & 0.000000\end{array}$

\section{KESIMPULAN}

Dari hasil penelitian penulis lakukan didapatkan kesimpulan jumlah produksi yang optimal adalah memproduksi yaitu Coca Cola $295 \mathrm{ml}$ sebanyak 440548 botol/tahun, Sprite $295 \mathrm{ml}$ sebanyak 44604 botol/tahun dan Frestea $220 \mathrm{ml}$ sebanyak 464848 botol/tahun dan pendapatan maksimal yang akan diperoleh PT. Coca Cola Amatil Indonesia Central Sumatera adalah sebesar $\mathrm{Rp}$ 2.235.097.000,- (dua milyar dua ratus tiga puluh lima juta Sembilan puluh tujuh ribu rupiah).

\section{DAFTAR KEPUSTAKAAN}

Agustini, Dwi Hayu. Riset Operasional Konsep - Konsep Dasar. Rineka Cipta, Jakarta, 2004.

Ahyari, Agus. Manajemen Produksi. BPFE. Yogyakarta. 1986

Assauri, Sofyan. Manajemen Produksi dan Operasi. Edisi 4, Fakultas Ekonomi Universitas Indonesia Jakarta. 1999.

Baroto, Teguh. Perencanaan dan Pengendalian Produksi. Ghalia Indonesia, Jakarta. 2002.

Hiller, Frederick S, dan Liberman, Gerald J. Pengantar Riset Operasi. Edisi Kelima. Erlangga, Jakarta. 1990.

Mulyono, Sri. Riset Operasi. Edisi Revisi. Fakultas Ekonomi Universitas Indonesia, Jakarta.2004.

Kuncoro, Mudrajad. Metode Kuantitatif. Edisi Pertama.Unit Penerbit dan Percetakan AMP YKPN.Yogyakarta.2001

Taha, Hamdy A. Riset Operasi. Binarupa Aksara.Jakarta.1996
M.Hum,Suwartono Dr. Dasar-dasar Metodologi Penelitian. Penerbit Andi. Yogyakarta.2012

Wijaya, Andi. Pengantar Riset Operasi. Edisi 3. Penerbit Mitra Wacana Media. Jakarta 2014

Hansen, Don R dan Maryanne M Mowen, Akuntansi Manajemen, Salemba Empat, Jakarta, 2002.

Horngren, Charles T, Srikant M Datar dan Madhav V Rajan, Akuntansi Biaya, Jilid 1, Terjemahan Adhariani, Desi, PT Indeks Kelompok Gramedia, Jakarta, 2005.

Sugiyono, Metoda Penelitian Kuantitatif Kualitatif dan R\&D, Alfabeta, Bandung, 2011.

Syamsuddin, Lukman, Manajemen Keuangan Perusahaan, PT Raja Grafindo Persada, Jakarta, 2004. 